\title{
BMI Global Health Ethics in times of conflict: some reflections on Syria, in the backdrop of Iraq
}

\author{
Kasturi Sen, ${ }^{1}$ Hamid Hussain, ${ }^{2}$ Waleed Al-Faisal ${ }^{3}$
}

To cite: Sen $\mathrm{K}$, Hussain $\mathrm{H}$, Al-Faisal W. Ethics in times of conflict: some reflections on Syria, in the backdrop of Iraq. BMJ Global Health 2016;1: e000149. doi:10.1136/ bmjgh-2016-000149

Received 5 August 2016 Accepted 1 November 2016

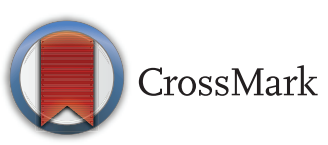

${ }^{1}$ Wolfson College (CR), Oxford, UK

${ }^{2}$ Faculty of Medicine, University of Baghdad, Baghdad, Iraq

${ }^{3}$ Faculty of Medicine, University of Damascus, Damascus, Syrian Arab Republic

Correspondence to Dr Kasturi Sen; info.bmjgh@bmj.com

\section{ABSTRACT}

Ethical challenges facing research and reporting from conflict-affected zones are well known; among them is the difficulty of finding reliable information; the tendency to take sides and define actors as either good or evil; the precarious security situation of residents and the ever-changing scenarios on the ground. We observed, however, that these challenges go unacknowledged in research and reporting on health state and on the health system from the conflict in Iraq and Syria, with the lines between science and journalistic reporting routinely blurred in the literature. What should be the restraining factor of academic research against prejudiced reporting on injury, death and the healthcare system has mostly failed in the Syrian conflict. Even social media, with its promise of 'independent' and 'citizens' voice', can be skewed, with much of the output in the Syria crisis coming from one side only, largely due to access issues. While researchers in conflict-affected zones, such as Syria, may need to take a position on one side or another when reporting, death, destruction and disease, it is important that they admit to the challenges of accessing unbiased data, the near impossibility of obtaining representative samples and the risk of the contamination of evidence, clinical or otherwise. The example of the Syrian and Iraqi conflicts (as context) indicates a need to reassess research ethics in conflict zones and their implications for policy.

\section{INTRODUCTION}

\begin{abstract}
You can report objective facts selectively and without context and give someone an impression. (Sacco, interview 2014) ${ }^{12}$
\end{abstract}

Anthropologist Ken Wilson, writing almost two decades ago, posed important questions about the ethics of research and reporting from regions in conflict; issues that continue to plague us, such as the challenge of identifying the truth among competing narratives in highly politicised conflict and postconflict environments. ${ }^{3}$ Most recently, in reporting on the conflicts in Iraq and Syria, we have observed that the challenges of politicisation remain endemic, despite guidelines from
Summary box

- There are ethical and scientific challenges of undertaking research and reporting from conflict zones with a focus on Iraq (as backdrop) and Syria over the past five years, as examples.

- The traditional boundaries between media reports (including social media) and research for Syria are blurred, in part, due to the difficulties of accessing conflict regions as well as political bias; the standards of research ethics and rigour are undermined by one-sided opinion on the conflicts in Iraq and Syria.

- Distorted research and reporting have negative consequences for peace and security and impact negatively on civilian life and on public health.

institutions, such as the American Anthropological Association, on the principle of "do no harm'" and the American Public Health Association guidelines for public health professionals working in conflict zones. ${ }^{5}$

In a recent publication, Cramer et $a t^{6}$ suggest that the challenges involved in research and reporting from conflict-affected zones include protection of informants, reducing risks for the research team and finding reliable information in a climate infused with 'rumor, silence, innuendo and suspicion'. Thomson et $a l$ and Ford et al emphasise the emotional and ethical challenges of field work in conflict zones, including the need for researchers to recognise the power they have over their research participants. This they suggest is at the core of the ethical implications because often participants as such will be left behind to face the consequences of research outputs. ${ }^{78}$

In early 2001, we experienced an instance of what could be fallout of the ethical issues of research in conflict-affected countries. In an interview with the director of a welfare organisation in south Lebanon, the first question asked was 'have you come to write lies about us?'. We had to assure him that we 


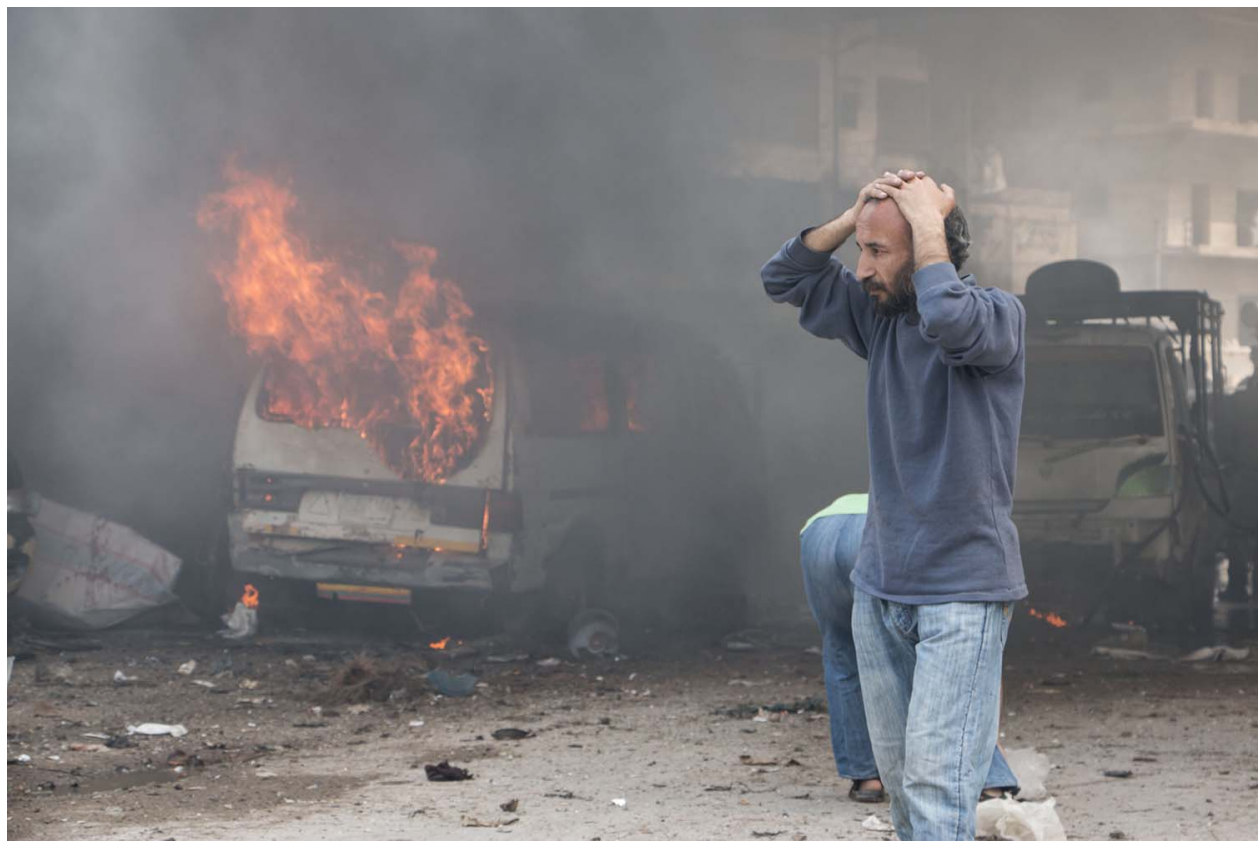

Permission obtained from WHO Syria/Karam Al-Masri.

were there to explore health and welfare provision in a country affected by prolonged conflict and that theirs was one organisation that interested us. It took a while to convince him that this would truly be the case.

If high standards can be maintained, taking into account a multitude of pressures as researchers (including the requirement for 'relative objectivity' under extreme contexts), we might congratulate ourselves. But even an exploratory assessment of reporting of the Middle East and North Africa (MENA) region in conflict (in this case of wars in Iraq and in Syria) suggests otherwise. For example, routinely, there we found lines between research and journalistic reporting blurred in the health literature with the exception of a handful of publications which addressed public health issues without advocating 'regime change'. ${ }^{9-14}$

The literature on conflict in Syria and Iraq has flourished since the inception of both wars; the Lancet series on Iraq was one example of this. ${ }^{15-18}$ More recently, for Syria, instead of a separation between science and journalistic reporting, the lines are blurred, with prejudice and polarisation contaminating both science and research ethics. ${ }^{i}$ The implications are ominous for the future of health research and for the prospects of health, peace and security for victims of conflict. In this analysis article, we combine an exploratory perspective on health research

${ }^{\mathrm{i}}$ The American Public Health Association outlines the role of public health practitioners and researchers in a conflict zone: 'In addition, public health practitioners could develop indicators related to public health and performance of health services, strengthen data collecting and surveillance techniques to address health status in conflict-affected populations, and devise and improve methods to analyze the impact of conflicts on health systems and how best to respond'. from conflict regions with our personal experience of working in the MENA region for over two decades.

\section{IRAQ}

Fifteen years following our experience in south Lebanon, few lessons appear to have been learnt from the 'embedded' narratives of 'good' and 'evil' of the Iraq war. That this narrative was orchestrated by a US-led coalition, to retain a monopoly on news of the human cost of the invasion and on the polity and society of Iraq, is well documented. During the 2003 Iraq invasion, ground realities affecting civilians were reported by journalists 'embedded' in the front line, meaning all information was derived from the US-led coalition front. The global audience rarely received information independent of the military. Since the war had caused a huge rift between the public and political leaders in the Western world, there was need to control its outputs. The false trigger for the war, that is, the Weapons of Mass Destruction, was unravelled only afterwards, marking the Iraq war as one of the biggest Western follies of the 20th century, for its human, economic, social and political consequences. ${ }^{16-22}$

Results of civilian deaths published by the Lancet in 2006 undermined official narrative on 'precision' bombing and 'targeted' warfare. Researchers in the USA and Europe challenged its findings, mostly on methodological grounds; some led by coalition governments, others with considerable chagrin. ${ }^{1623}$ The credibility of authors, the methodology used and even the possibility of a 'conspiracy' by the Lancet were raised due to the date of publication, prior to a US election. While such challenges within and across scientific research are routinely part of academic discourse, the systematic attempts 
at discrediting data from the study of Burnham and colleagues in the Lancet, against embedded reporting, established an ominous trend: it highlighted attempts to influence science with journalistic reporting and official discourse on the war in Iraq. This kind of pressure is of concern because many reporters 'embedded' in Iraq have since admitted they regretted not cross-checking evidence provided by the coalition forces. ${ }^{19-21}$ Despite this, however, had it not been for WikiLeaks (in 2010), we would probably never have known of systematic abuse at Abu Ghraib prison, or of the executions of innocent civilians by members of the US army and its subcontractors. Their mission to promote democracy was often in total violation of the international laws guiding rules of engagement in conflict. ${ }^{192425}$

\section{SYRIA}

Attempts to suppress evidence of civilian impact and conflicting evidence from the Iraq invasion were, for many of us, an important landmark in the ethics of research on the human consequences of conflict. It is in this context that one might gaze with alarm at the erosion of 'relative objectivity' and ethics of research and reporting on the Syrian conflict. Unlike Iraq, the conflict in Syria has involved extensive fighting within the country. The controversy facing research from Iraq was mainly over the numbers of deaths and how they were calculated. These provide some parallels in the case of Syria; on the control of information, how and from where it is derived and the extent to which it fits into the dominant discourse on the Syrian conflict. ${ }^{20} 2627$ This narrative has, to date, doggedly focused on an “"evil" regime' on a relentless killing spree of its own citizens. Except for extensive description of the barbarity of the so-called Islamic State of Iraq and Syria (ISIS), much of the reporting on the Syrian conflict is framed in terms of the need for regime change, as was the case for Iraq and Libya. ${ }^{28-33}$ Public health research reports have often followed suit, with political discourse on fleeing medics, murdered health workers, destroyed hospitals, the denial of polio vaccinations to children and infants, in 'opposition',ii held areas, sieges, forced starvation and the torture of civilians to death. These reports have reinforced the narrative of 'good and evil' in the case of Syria more so than in Iraq. ${ }^{30}$ 34-36

Some claim, perhaps with legitimacy, that it is a near impossible task to provide fair representation in any conflict. ${ }^{6}$ There is always a different story. But where this is the case, one needs to take a position on one side or another, declare it and move forward. For researchers working in conflict regions, this involves admitting to the

\footnotetext{
${ }^{i i}$ Opposition Held areas in Syria-North East of the country, Eastern section of Aleppo and suburbs of Damascus. On no account is there a 'unified opposition', there are key groups which receive external funds and training as well as hundreds of smaller groups unified by tribal identity throughout the country. A large section of a floating opposition is resident in Turkey and supported by the Turkish state.
}

challenges of accessing unbiased data, the near impossibility of obtaining 'representative' samples and the risk of the contamination of evidence. Anthropologist Elizabeth Wood argued that the "ethical imperatives of research ('does no harm') is intensified in conflict zones due to... [] political polarization, the presence of armed fighters and the precarious security of most residents." ${ }^{37}$ To these, one may add the ever-changing scenarios on the ground, from a military and a humanitarian perspective. For Ken Wilson, "researching in an 'ethical manner' seems not about proclaiming good and evil, but about enabling the reader to hear the voices and appreciate the actions of as many of the different people involved as possible." ${ }^{3}$ Indeed, contextualising the differing perspectives of different people can give a more accurate representation of the multiple truths in these settings.

However, despite such limitations, humanitarian organisations, such as the WHO, the International Committee of the Red Cross (ICRC) and the United Nations Relief and Works Agency for Palestine Refugees in the Near East (UNRWA), do require accurate information on deaths and injuries in order to address urgent humanitarian need and implement emergency health programmes. In the case of Syria, they do not appreciate inflammatory language for the protection of humanitarian function on the ground. But such pleas are mostly ignored by NGOs operating from 'opposition' held areas, ${ }^{34-36} 38$ whose reports are regularly quoted in international journals and by Western governments, and have a powerful effect on public perception and policy. Unfortunately, as of 2014, the United Nations admitted that it had become wellnigh impossible to provide accurate data on mortality and morbidity in Syria. ${ }^{27} 39$ So now, the outside world has to rely almost entirely on these NGOs to know of death and injury in this conflict. Where there is bias of onesided reporting, it can compromise staff on the ground (mostly nationals) as well as humanitarian programmes, breaching the principle of 'do no harm' highlighting a lack of ethics and principles, even of 'neutrality'. This remains a major challenge for research and reporting from this region. However, admitting that one is writing from one side, thereby not presenting the impression of impartiality, is one way to resolve this anomaly. ${ }^{39}$

\section{ROLE OF SOCIAL MEDIA IN SYRIAN CONFLICT}

First and foremost, research and reporting on the Syrian conflict has been hugely influenced by social media, in English and in Arabic, contrary to what happened during the Iraq war. This phenomenon is viewed as a positive one, due to the apparent liberation of the source of information from 'state' control whether inside or outside the conflict zone, thus representing 'citizens' voice'. In this case, we considered mainly the English language media; we felt that it has greater influence on Western public perception and policy towards Syria. It is pertinent, however, to question whether the widespread use of the English language social media as 
a key source of information has led to a diversity of views and a constructive exchange on the conflict. Sacco and Bossio, who monitor the use of social media in conflict, advocate caution and suggest that such reports often represent one-sided perspectives. ${ }^{2}{ }^{26}$ Actual reporting from Syria whether through social media or in the presence of reporters and researchers suggests that much of it has taken place exclusively from 'opposition' sites. This is rarely acknowledged in most outputs, whether in research or in news reports. With the exception of a small handful of scientific papers, the critical eye of academic research over reportage is lost in the case of Syria. $^{9-13} \quad 39-41$ Instead, there is an unhealthy overlap between the two, to the detriment of critical appraisal of public health challenges on the ground..$^{92-32} 42$

In a 2014 study, Lynch et al highlighted, "Syria's has been the most socially mediated civil conflict in history. An exceptional amount of what the outside world knows... has come from videos, analysis, and commentary circulated through social networks." Unfortunately, much of the social media output in the Syria crisis has come from one side only largely due to access issues. In theory, given the research/information/control controversy in Iraq, this is a positive development. However, Lynch $e t a l$ s analysis of the use of social media reporting on Syria over a 2-year period suggests that despite widespread use, and lauding as 'independent', the risk of manipulation for political ends is high 'given that there are few journalists or international observers on the ground to scrutinize and provide external validity checks of claimed materials. These [which] have informed international relief efforts, assessments of the identity and character of the rebel fighting groups, and debates about international intervention'. ${ }^{26}$

The over-reliance on social media, embedded in 'opposition' areas, explains the bias in reporting and research on the conflict in Syria. But as Lynch and colleagues ask, 'how credible is such information? How was it produced? Why did some such reports gain attention of researchers whilst others, equally intriguing, fade into obscurity'? ${ }^{26}$ These questions remain unanswered for the conflict in Syria. The findings of the Lynch et al study suggest highly sophisticated methods of deception embedded in social media messages that require caution, rather than routine affirmation as 'citizens' voice'. Since social media outputs are rarely cross-checked, they are subject to manipulation for political use. Lynch et $a l^{26}$ argue that we need 'far better tools for sentiment analysis to speak with confidence about the real political meaning of identified clusters and trends' ${ }^{26}$

\section{EVIDENCE FROM THE FIELD}

Further, one sidedness is reflected in many scientific papers in public health journals, which continue to claim that the overwhelming majority of destruction in the public health sphere (hospitals, health centres and health clinics) are caused by 'regime bombardment'. Some even claim that this amounted to $98 \%$ of the destruction to date. In these publications, ethical perspectives, doubts and reservations are mostly absent, despite the clear challenges of writing from a conflict zone, and the tendency to source information from one side only. ${ }^{29}{ }^{32}$ The targeting of health workers is of major concern and this critical issue remains neglected in the case of Syria where several hundred health workers have been killed, more than 175 last year alone. According to the WHO, more than half of all health workers had left the country by $2015 .^{10} 43{ }^{44}$ But reading reports and 'scientific' articles, on such deaths unsurprisingly, the majority are attributed to 'regime forces' that have 'deliberately' targeted them. Even if such 'deliberate targeting' occurs in times of conflict, few publications recognise that no war is fought by one side alone. This is particularly relevant for Syria where several hundred armed insurgent groups operate in different regions of the country and where people remain in desperate need of medical care and supplies. ${ }^{45}$ Some international organisations, working inside Syria, report routine attacks on facilities and personnel from armed groups as well as the State, fighting in 'opposition' held areas. ${ }^{10} 434446$

Owing to the growing concern in the humanitarian community about the plight of health workers, the ICRC commissioned a 2-year study of 16 countries in conflict. The methods were based on an analysis of reports from each country over a 2.5 year period, followed by statistical modelling of results. The information was derived mainly from humanitarian organisations, including the ICRC and open sources, such as websites and media reports. While the study did not include data from Syria, its findings can help us reflect on the context of conflict. They show that the majority of attacks on health facilities were undertaken by armed groups $(36.5 \%)$, while $33 \%$ of violence was committed by the State, in these cases, mostly in the thick of fighting. ${ }^{\text {iii }} 147$ The key issue is that the ICRC study provides some indication of the complexity of conflict contexts that reflects current reporting and tenor of public health research from Syria; routinely for Syria, one side alone (the State) is attributed blame for destruction of all health facilities, the flight and the deaths of all health workers, when in reality, multiple sides are involved in this conflict. Thus, caution is required when presenting research findings regarding differences between damage to infrastructure often clearly visible and casualty figures that are less visible and often not reliable. Journalistic reporting has little compulsion to make distinctions where researchers have a responsibility to do so. ${ }^{28} 3242$ The ICRC findings highlight the ease with which bias can creep into a report,

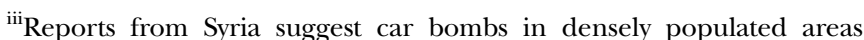
create more civilian casualties than an air raid which destroys buildings and infrastructure. But the main issue is the challenge of accurate data on destruction and death from any conflict whether in Syria or elsewhere and especially when multiple parties are involved. ${ }^{1}$ A point also reiterated by the WHO dashboard on attacks on health facilities worldwide.
} 
hence the need to acknowledge boundaries between reporting an event and researching one. ${ }^{27} 3947$

\section{CONCLUSION}

The restraining factor of academic research against journalistic reporting has mostly failed in the Syrian conflict with few lessons gleaned from embedded reporting in Iraq. Instead, it has created an atmosphere of polarisation and hostility where the conflict is perceived almost entirely in 'black and white'. As a result, 'opposition' groups have continued to receive funding from external sources in the belief that most of them other than ISIS are fighting a just cause. The conflict has evolved into a self-fulfilling prophecy. The regime is conjectured as 'evil', while 'opposition' fighters (excluding ISIS) are fighting a just cause. The demonisation of the 'regime' has meant ongoing Western sanctions that has not resulted as intended, in its ouster, but reinforced its presence; much worse it has wreaked havoc on the population at large, in particular, the health of vulnerable groups, such as pregnant women, children and older people. Escalating food prices, the looting of water and electricity by armed groups, making most basic essentials either unaffordable or unavailable in large parts of the country are ignored by Western policy. The devastating consequences of ongoing conflict and sanction are slowly beginning to emerge and could surpass the grim health outcomes of sanctions imposed on Iraq. ${ }^{12} 40$ 48-50

Combined with harsh sanctions, the one-sided narrative in research and reportage has contributed to a further dispersal of people escaping the fighting, seeking food and shelter to neighbouring countries and into Europe. The Syrian conflict urgently requires a reassessment of research ethics from conflict zones, how distortions contribute to the prolongation of conflict and the implications for policy.

Handling editor Seye Abimbola.

Acknowledgements The authors express their gratitude for the comments of two anonymous reviewers.

Contributors KS conceived the paper with extensive comments from $\mathrm{HH}$ and remarks from WA-F.

Competing interests None declared.

Provenance and peer review Commissioned; externally peer reviewed.

Data sharing statement No additional data are available.

Open Access This is an Open Access article distributed in accordance with the Creative Commons Attribution Non Commercial (CC BY-NC 4.0) license, which permits others to distribute, remix, adapt, build upon this work noncommercially, and license their derivative works on different terms, provided the original work is properly cited and the use is non-commercial. See: http:// creativecommons.org/licenses/by-nc/4.0/

\section{REFERENCES}

1. BBC. Homs and Damascus bomb blasts kill 140. BBC, 2016.

2. Sacco V, Bossio D. Using social media in the news reportage of War and conflict: opportunities and challenges. J Media Innovation 2015;2:59-76.
3. Wilson $\mathrm{K}$. Thinking about the ethics of field work in developing countries. In: Devereaux S, Hoddinott J, ed. Fieldwork in developing countries. Lynne Rienner, 1993:179-99.

4. American Anthropological Association. Ethics Task Force: draft principle: do no harm. 2015.

5. American Public Health Association. The role of public health practitioners, academics and advocates in relation to armed conflict and War. 2014 Policy Statement.

6. Cramer C, Hammond L, Pottier J. Researching violence in Africa ethical and methodological challenges (Africa-Europe for interdisciplinary studies). Vol 6. London: Brill, 2011:1-184.

7. Ford N, Mills EJ, Zachariah R, et al. Ethics of conducting research in conflict settings. Confl Health 2009;3:7.

8. Thomson S, Ansoms A, Murison J. Emotional and ethical challenges of field research in Africa. Thomson S, Ansoms A, Murison J, eds. In: Academic integrity and ethical responsibility in post genocide Rwanda. London: Palgrave Macmillan, 2013; Chapter 11:139-54

9. Bashour $\mathrm{H}$. Lets not forget the Health of Syrians within their own country. Am J Public Health 2015;105:2407-8.

10. Muhjazi G, Bashour $\mathrm{H}$, Abourshaid N. An early warning and response system for Syria. Lancet 2013;382:2066.

11. Al Faisal W, Al Saleh Y, Sen K. Syria: public health achievements and sanctions. Lancet 2012;379:2241.

12. Al-Faisal W, Sen K, Al Saleh $\mathrm{Y}$, Syria: end sanctions and find political solution to peace. Lancet Glob Health 2015;3:e363.

13. Ratanayake R. The public health impact of the Syrian crisis. Confl Health 2015;9.

14. Sen K, Al-Faisal W. Syria: neo liberal reforms in health sector financing_embedding unequal access? Soc Med 2012;6:171-82.

15. Burnham G, Lafta R, Doocy S, et al. Mortality after the 2003 invasion of Iraq: a cross sectional cluster sample survey. Lancet 2006;368:1421-8

16. Hagopian A, Flaxman AD, Takaro TK, et al. Mortality in Iraq associated with the 2003-2011 war and occupation: findings from a national cluster sample survey by the university collaborative Iraq Mortality Study. PLoS Med 2013;10:e1001533.

17. Horton R. The war in Iraq: civilian casualties and political responsibilities. Lancet 2004;364:1831.

18. Horton R. Iraq: time to signal a new era for health in foreign policy. Lancet 2006;368:1395-7.

19. Allan $\mathrm{S}$, Sonnawalkar $\mathrm{P}, \mathrm{Carter} \mathrm{C}$. Bearing witness: citizen journalism and human rights issues. Global Soc Educ 2007:5:373-89.

20. Cockburn P. Lies damn lies: reports of battlefield atrocities. The Independent 6 November 2011.

21. Dewachi O, Skelton M, Nguyen VK, et al. Changing therapeutic geographies of the Iraqi and Syrian wars. Lancet 2014;383:449-57.

22. Tuosto K. The 'Grunt Truth' of embedded Journalism - the new media-military relationship. Standford J Int Relations 2008:X:1-12.

23. Guha-Sapir D, DeGomme O, Pederson J. Mortality in Iraq. Lancet 2007:369:140-6.

24. Wikileaks. Abu Graib Torture and Prisoner Abuse. 2010.

25. The Watson Institute for International and Public Affairs. The human cost of War in Afghanistan, Pakistan and Iraq: executive summary. USA: Watson Institute MIT USA, 2009:1-3.

26. Lynch M, Freedon S, Alaay D. Syria's socially mediated civil war: blogs and bullets. In: Ron Paul Institute, ed. Washington, USA United States Institute for Peace and Prosperity 91, 2014:1-38.

27. Slemrod A. Counting under fire: the untold story of Syria's casualty figures. IRIN, 2015. Relief Web IRIN.

28. Hallam R. Response to Syria's health crisis. Lancet 2013;382:679-80.

29. Heisler M, Baker E, Mckay D. Attacks on health care in Syrianormalizing violations of medical neutrality? N Engl J Med 2015;373:2489-91.

30. Syria's health and humanitarian crisis. Lancet 2012;379:590.

31. Sahloul Z, Coutts A, Fouad FM, et al. Health response system for Syria: beyond official narrative. Lancet 2014;383:407.

32. Ben Taleb Z, Bahelah R, Fouad FM, et al. Syria: health in a country undergoing tragic transition. Int $J$ Public Health 2015;60(Suppl 1): S63-72.

33. Tarakji A. How can there be peace when regime is starving thousands of Syrians. Independent 2016;1.

34. Amnesty International. Health Crisis: Climate of fear in Syria's hospitals as patients and medics are targeted. USA: Amnesty USA. 2011, 141.

35. Human Rights Watch. Death from the Skies: deliberate and indiscriminate air strikes on civilians. WA: HRW-USA, 2013: 1-86. ISBN: 978-1-62313-0039.

36. International Rescue Committee. 'Increase in Air Strikes and ongoing sieges making mockery of int. efforts to help Syrians' says Aid agency. 2016 
37. Wood EJ. The ethical challenges of research in Conflict Zone. Qual Sociology (Special Issue: Political Ethnography) 2006;29: 373-86.

38. MSF. Syria dossier: medicine as a weapon of persecution. 2012

39. Hiroyuki A, Shingo H. Political Bias lurking in Fatality Statistics Published by the Syrian Observatory for Human Rights. Contemporary Middle East Political Studies in Japan (CMEP), ed. Japan: CMEP-J, 2015: 1-3. CMEPS-J Report no. 1.

40. Sen K, Al-Faisal W, AISaleh Y. Syria: effects of conflict and sanctions on public health. J Public Health (Oxf) 2013;35:195-9.

41. Thomas E. Syria's disabled future. Middle East Research and Information Project (MERIP), 2013:1-6.

42. The war on Syrian civilians. Lancet 2014;383:383.

43. WHO, UNICEF. Statement on attacks on medical facilities and personnel in the Syrian Arab Republic. WHO, ed. Geneva: World Health Organisation, 2016:1.
44. WHO E. Health situation in Syria and WHO response. Cairo, Egypt: WHO-EMRO, 2012:1-20

45. World Health Organisation-Eastern Mediterranean Regional Office. The Syrian Arab Republic Crisis-meeting humanitarian health needs. WHO-EMRO, ed. Cairo, WHO-EMRO, 2012.

46. WHO. WHO attacks dashboard. 2016.

47. International Committee of the Red Cross. Health care in danger: a sixteen country study. Geneva: ICRC, 2011: 1-19. Health Care in Danger.

48. Garfield R. The impact of economic sanctions on health and well being. Van Brabant K, ed. London: Overseas Development Institute. Relief and Rehabilitation Network, 1999: 31, 1-40.

49. Gordon J. Economic sanctions, just war doctrine, and the 'Fearful spectacle of the civilian dead'. New York, USA, 2004.

50. Sanctions Hit Humanitarian Aid to Syria, IRIN on line, Damascus, Syria, 2013, pp 1-2. 